\title{
PELATIHAN DAN PENDAMPINGAN PENULISAN KARYA TULIS ILMIAH BAGI GURU SD
}

\author{
Ilfiandra' ${ }^{1}$, Uman Suherman², Sudaryat Nurdin Akhmad ${ }^{3}$, Amin Budiamin $^{4}$, \\ Setiawati ${ }^{5}$
}

\begin{abstract}
Abstrak: Tujuan umum kegiatan ini adalah tersedia guru SD yang kompeten dalam menulis karya ilmiah pengembangan profesi guru. Secara operasional, tujuan kegiatan ini adalah: 1) Tersedia guru yang terampil dan siap melaksanakan sosialisasi ragam jenis pengembangan profesi guru; 2) Terbantunya guru untuk mampu mengembangkan profesi, khususnya dalam penulisan karya tulis ilmiah (KTI) hasil penelitian tindakan kelas (PTK); 3) Terbinanya guru dalam melakukan PTK di kelas yang dibinanya; 4) Terbinanya guru dalam menyusun laporan penelitian dan artikel jurnal ilmiah hasil kegiatan PTK; 5) Tersusunnya laporan penelitian dari kegiatan PTK yang ditulis oleh guru; dan 6) Terbitnya jurnal edisi khusus yang memuat artikel hasil kegiatan PTK yang ditulis oleh guru. Untuk mencapai tujuan tersebut digunakan metode pelatihan, lokakarya, dan pendampingan. Pada akhir kegiatan program ini diperoleh hasil: 1) Sebanyak 27 orang guru SD Golongan IVa mengikuti kegiatan pelatihan secara utuh selama 26 jam pelajaran; 2) Terlaksana empat kali pendampingan dalam kegiatan perencanaan, pelaksanaan, dan penulisan laporan PTK; 3) Tersedia 27 laporan hasil PTK yang sendiri oleh setiap peserta dengan bimbingan dan arahan tim pendamping; 4) Tersedia 27 artikel hasil PTK yang memungkinkan dimuat dalam jurnal berkala lokal, nasional, maupun nasional terakreditasi; 5) Terbentuk penerbitan berkala lokal "MANONJAYA" untuk publikasi hasil-hasil PTK guru; dan 6) Dua artikel terbaik yang siap dimuat pada terbitan berkala yang diterbitkan oleh lembaga di lingkungan UPI.
\end{abstract}

Kata Kunci: Lokakarya, PGRI, PTK, SD.

\section{The Training and Assistance of Writing Paper for Elementary School Teachers}

\begin{abstract}
The main goal of this program is supplying elementary school teachers who have competence in writing paper on developing teacher profession. Operationally, the goals of program are: 1) supplying skilled teachers who are ready to do socialization many kinds of developing of teacher profession; 2) helping teacher to be able to develop their profession especially in writing scientific paper of result of classroom action research (PTK); 3) skilling teachers in conducting classroom action research in their classroom; 4) skilling teachers in arranging report of research and scientific journal article of PTK result, and 6) publishing special edition journal that contained the article of PTK result that written by teachers. For pursuit the goals, here it is using methods of training, workshop ad assistance. In the end of this program, the gained result are: 1) there are 27 elementary teachers class of IVa participating the training program wholly in 26 hours of lesson; 2) 4 times of assistance program have been conducted in

\footnotetext{
${ }^{1}$ Departemen Psikologi Pendidikan dan Bimbingan FIP Universitas Pendidikan Indonesia, Jalan Dr. Setiabudhi No. 229 Bandung 40154; email: ilfiandra@upi.edu.

2 Departemen Psikologi Pendidikan dan Bimbingan FIP Universitas Pendidikan Indonesia; email: umans@upi.edu.

${ }^{3}$ Universitas Pendidikan Indonesia; email: sunurakhmad@upi.edu.

${ }^{4}$ Universitas Pendidikan Indonesia; email: abudiamin@upi.edu.

${ }^{5}$ Universitas Pendidikan Indonesia; email: setiawati_bk@upi.edu.
} 
several activities of planning, actuating, and writing report of PTK; 3) 27 report of PTK are supplied by every participants by guiding and directing of assistance team; 4) 27 articles of PTK result are supplied that is possibly published in local journal or national; 5) a publisher is built in local of "MANONJAYA" for promoting result of teacher PTK; and 6) the best two articles are ready to be published by publisher in UPI.

Keywords: PGRI, PTK, SD, Workshop.

\section{PENDAHULUAN}

Dalam skenario global, sumber keunggulan bersaing yang paling vital bagi suatu institusi harus bertumpu pada sumber daya manusia (SDM) yang berkualitas serta bagaimana memanajemeninya. Bagi Indonesia, upaya memenuhi tuntutan tersebut bukan hal mudah karena berbagai laporan internasional mengindikasikan bahwa kualitas SDM yang ada selama ini sangat ketinggalan dibanding negara lain.

Tanpa berpretensi untuk mengurangi makna pentingnya faktor determinan lain dan mereduksikan serta menciutkan martabat SDM sebagai hasil upaya lainnya, rendahnya kualitas SDM Indonesia itu terjadi karena mutu pendidikan yang rendah. Aktor utama yang paling sering dianggap paling bertanggung jawab atas rendahnya kualitas pendidikan adalah mutu dan prestasi kerja para guru yang rendah. Hal ini dapat dipahami karena kualitas pendidikan amat ditentukan oleh kualitas guru.

Menyadari hal tersebut, dalam Undang-undang No 14 Tahun 2005 tentang Guru dan Dosen ditegaskan bahwa guru merupakan profesi yang menuntut seperangkat kompetensi dan kualifikasi tertentu. Seperti dinyatakan pada bagian ketentuan umum pasal 1 ayat 10 bahwa Kompetensi adalah seperangkat pengetahuan, keterampilan, dan perilaku yang harus dimiliki, dihayati, dan dikuasai oleh guru atau dosen dalam melaksanakan tugas keprofesionalan. Lebih jauh pada pasal 2 ayat 1 dinyatakan bahwa guru mempunyai kedudukan sebagai tenaga profesional pada jenjang pendidikan dasar, pendidikan menengah, dan pendidikan anak usia dini pada jalur pendidikan formal yang diangkat sesuai dengan peraturan perundangundangan.

Lebih jauh, kompetensi yang dituntut bagi seoarang guru seperti dinyatakan pada peraturan pemerintah Nomor 19 Tahun 2005 dan ditegaskan kembali pada Undang-Undang tentang Guru dan Dosen pasal 8 bahwa guru wajib memiliki kualifikasi akademik, kompetensi, sertifikat pendidik, sehat jasmani dan rohani, serta memiliki kemampuan untuk mewujudkan tujuan pendidikan nasional. Kompetensi itu seperti dinyatakan pada pasal 8, meliputi kompetensi pedagogik, kompetensi kepribadian, kompetensi sosial, dan kompetensi profesional yang diperoleh melalui pendidikan profesi.

Sesuai dengan kompetensi itu maka guru dipandang sebagai tenaga profesional yang harus memenuhi kriteria sebagai berikut.

1) Memiliki bakat, minat, panggilan jiwa, dan idealisme; 
2) Memiliki komitmen untuk meningkatkan mutu pendidikan, keimanan, ketakwaan, dan akhlak mulia;

3) Memiliki kualifikasi akademik dan latar belakang pendidikan sesuai dengan bidang tugas;

4) Memiliki kompetensi yang diperlukan sesuai dengan bidang tugas;

5) Memiliki tanggung jawab atas pelaksanaan tugas keprofesionalan;

6) Memperoleh penghasilan yang ditentukan sesuai dengan prestasi kerja;

7) Memiliki kesempatan untuk mengembangkan keprofesionalan secara berkelanjutan dengan belajar sepanjang hayat;

8) Memiliki jaminan perlindungan hukum dalam melaksanakan tugas keprofesionalan; dan

9) Memiliki organisasi profesi yang mempunyai kewenangan mengatur halhal yang berkaitan dengan tugas keprofesionalan guru.

Untuk memberikan peluang kepada guru menjadi tenaga profesional, terdapat ayat yang menyatakan peluang bagi guru untuk memenuhinya, seperti dinyatakan pada pasal 7 ayat 2, bahwa pemberdayaan profesi guru atau pemberdayaan profesi dosen diselenggarakan melalui pengembangan diri yang dilakukan secara demokratis, berkeadilan, tidak diskriminatif, dan berkelanjutan dengan menjunjung tinggi hak asasi manusia, nilai keagamaan, nilai kultural, kemajemukan bangsa, dan kode etik profesi.

Sesuai dengan tuntutan di atas maka guru memiliki sejumlah hak yang harus dipenuhi oleh pemerintah pusat dan pemerintah daerah yaitu seperti diatur dalam pasal 14 ayat 1, bahwa dalam melaksanakan tugas keprofesionalan, guru berhak:

1) Memperoleh penghasilan di atas kebutuhan hidup minimum dan jaminan kesejahteraan sosial;

2) Mendapatkan promosi dan penghargaan sesuai dengan tugas dan prestasi kerja;

3) Memperoleh perlindungan dalam melaksanakan tugas dan hak atas kekayaan intelektual;

4) Memperoleh kesempatan untuk meningkatkan kompetensi;

5) Memperoleh dan memanfaatkan sarana dan prasarana pembelajaran untuk menunjang kelancaran tugas keprofesionalan;

6) Memiliki kebebasan dalam memberikan penilaian dan ikut menentukan kelulusan, penghargaan, dan/atau sanksi kepada peserta didik sesuai dengan kaidah pendidikan, kode etik guru, dan peraturan perundangundangan;

7) Memperoleh rasa aman dan jaminan keselamatan dalam melaksanakan tugas;

8) Memiliki kebebasan untuk berserikat dalam organisasi profesi; 
9) Memiliki kesempatan untuk berperan dalam penentuan kebijakan pendidikan;

10) Memperoleh kesempatan untuk mengembangkan dan meningkatkan kualifikasi akademik dan kompetensi; dan/atau

11) Memperoleh pelatihan dan pengembangan profesi dalam bidangnya.

Dalam upaya memenuhi tuntutan kualifikasi dan diikuti dengan hak yang seharusnya diperoleh seorang guru, dalam kenyataan masih demikian banyak tenaga guru yang tertahan pada golongan IVa. Ini terjadi karena bagi guru yang akan megajukan kenaikan pangkat/jabatan dari Pembina/IVa ke atas diwajibkan memenuhi angka kredit dari pengembangan profesi minimal 12 kredit. Pada kenaikan pangkat sebelumnya tidak diwajibkan memenuhi dan atau mempunyai kredit dari unsur pengembangan profesi sehingga dapat dilalui secara mulus oleh setiap guru. Masalah muncul ketika mereka akan naik pangkat dari IVa ke IVb dan seterusnya.

Kenyataan tersebut sejalan dengan pengalaman beberapa penilai karya ilmiah menunjukkan bahwa guru yang seharusnya menjadikan karya ilmiah sebagai bagian dari profesiannya tidak terbiasa untuk menulis dan mengembangkan menjadi karya ilmiah. Demikian pula dilihat dari persyaratan yang harus dipenuhi yaitu APIK (Asli, Perlu, IImiah dan Konsisten), dalam banyak hal tidak dapat dipenuhi dan bahkan hanya dipandang sebagai persyaratan semata dan mengabaikan ketentuan tersebut.

Secara konseptual, KTI merupakan suatu keniscayaan bagi guru sebagai tenaga profesi. Guru harus menulis KTI sebagai bagian esensial dari pengembangan profesinya. Dengan demikian tuntutan sebagai pendidik, akan selalu diperbaharui melalui upaya melakukan pengkajian dan tuntutan untuk mengamalkan kemampuan mendidik dan melakukan pengkajian ilmu yang ditekuninya dalam kehidupan sehari-hari. Pengembangan profesi seharusnya terus memacu mereka melakukan refleksi dan meningkatkan profesinya.

Mengingat kondisi yang terjadi saat ini, diperlukan berbagai upaya untuk membantu guru keluar dari masalah kesulitan memperoleh kredit dari karya tulis ilmiah. Untuk hal itu diperlukan penataran dan lokakarya dalam upaya mengembangkan kemampuan membuat karya tulis. Kegiatan yang dipandang paling memungkinkan dan hubungan dengan pembuatan karya tulis, serta dapat meningkatkan profesi dan kompetensinya dalam meningkatkan prestasi belajar siswa dan meningkatkan kinerja dalam melakukan proses pembelajaran yaitu melalui Penelitian Tindakan Kelas (PTK). PTK hakikatnya merupakan kegiatan ilmiah yang mampu merefleksikan kegiatan pembelajaran guru yang bersangkutan melalui prosedur ilmiah dan dapat dipertanggungjawabkan dengan prosedur dan persyaratan yang bisa dilakukan seorang guru tanpa mengurangi perhatiannya pada kelas dan prestasi siswa. Kegiatan penataran dan lokakarya mengenai PTK perlu dirancang dalam upaya meningkatkan kemampuan guru dan secara langsung mampu melakukan kegiatan penelitian.

Pengembangan profesi terdiri dari lima macam kegiatan, yaitu: (1) menyusun Karya Tulis IImiah (KTI), (2) menemukan Teknologi Tepat Guna, (3) 
membuat alat peraga/bimbingan, (4) menciptakan karya seni dan (5) mengikuti kegiatan pengembangan kurikulum. Tampak bahwa membuat Karya Tulis Ilmiah (KTI) merupakan salah satu macam kegiatan yang dapat dilakukan guru dalam pengembangan profesinya, bukan merupakan satu-satunya kegiatan pengembangan profesi guru. Namun, dengan berbagai alasan, antara lain karena belum jelasnya petunjuk operasional pelaksanaan dan penilaian dari kegiatan selain menyusun $\mathrm{KTI}$, maka pelaksanaan kegiatan pengembangan profesi sebagian terbesar dilakukan melalui KTI. KTI adalah laporan tertulis tentang (hasil) kegiatan ilmiah. Karena kegiatan ilmiah itu banyak macamnya, maka laporan kegiatan ilmiah (KTI) juga beragam bentuknya.

Salah satu bentuk KTI yang akhir-akhir ini, cenderung banyak dilakukan oleh para guru adalah $\mathrm{KTI}$ hasil penelitian perorangan yang tidak dipublikasikan, tetapi didokumentasikan di perpustakaan sekolah dalam bentuk makalah. Karya Tulis IImiah yang berupa laporan hasil penelitian tersebut cenderung diminati di antaranya karena:

1) Para guru makin memahami bahwa salah satu tujuan kegiatan pengembangan profesi, adalah dilakukannya kegiatan nyata di kelasnya yang ditujukan untuk meningkatkan mutu proses dan hasil pembelajarannya. Bagi sebagian besar guru, berkegiatan seperti itu, sudah terbiasa dilakukan.

2) Kegiatan tersebut, harus dilaksanakan dengan menggunakan kaidahkaidah ilmiah, karena hanya dengan cara itulah, mereka akan mendapat jawaban yang benar secara keilmuan terhadap apa yang ingin dikajinya.

3) Apabila kegiatan tersebut dilakukan di kelasnya, maka kegiatan tersebut dapat berupa penelitian tindakan yang semakin layak untuk menjadi prioritas kegiatan. Kegiatan nyata dalam proses pembelajaran, dapat berupa tindakan untuk "menerapkan" hal-hal "baru" dalam praktik pembelajarannya. Berbagai inovasi baru dalam pembelajaran, memerlukan verifikasi maupun penerapan dalam proses pembelajaran.

Mengapa Penelitian Tindakan Kelas (PTK) disarankan sebagai pengembangan profesi guru? PTK disarankan dilakukan guru dalam upaya menulis KTI karena: (1) KTI tersebut merupakan laporan dari kegiatan nyata yang dilakukan para guru di kelasnya dalam upaya meningkatkan mutu pembelajarannya (ini tentunya berbeda dengan KTI yang berupa laporan penelitian korelasi, penelitian diskriptif, ataupun ungkapan gagasan, yang umumnya tidak memberikan dampak langsung pada proses pembelajaran di kelasnya); dan (2) dengan melakukan kegiatan penelitian tersebut, maka para guru telah melakukan salah satu tugasnya dalam kegiatan pengembangan profesionalnya.

Justifikasi Tim Pengusul bersama mitra dalam menentukan upaya pengembangan profesi guru sebagai prioritas permasalahan yang harus ditangani, didasarkan atas pengalaman empirik dan diskusi mendalam. Inti permasalahan yang menajdi penyebab utama menumpuknya kepangkatan guru SD pada golongan IVa secara empirik terungkap ketika Tim Pengusul melakukan kegiatan sosialisasi kegiatan pengembangan profesi guru 
pembimbing di Kabupaten Bandung, Kota Bandung, dan Kota Cimahi atas dukungan dana dari PMPTK tahun 2006 dan kegiatan serupa atas kerja sama dengan Prof. Dr. Mohammad Surya (Mantan Ketua PB PGRI) pada awal tahun 2009 berupa sosialisasi pengembangan profesi guru bagi para guru SD di Kabupaten Cirebon, Kabupaten Kuningan, Kabupaten Tasikmalaya, Kabupaten Garut, Kabupaten Ciamis, Kota Cimahi, Kabupaten Bandung Barat, dan Kabupaten Cianjur. Di antara delapan kabupaten/kota tersebut yang paling banyak guru SD golongan IVa namun paling sedikit dapat naik pangkat ke golongan IVb ke atas (hanya dua orang) adalah Kabupaten Tasikmalaya. Hasil evaluasi kegiatan sosialisasi tersebut antara lain terungkap bahwa selama ini para guru SD di Kabupaten Tasikmalaya belum mengetahui bahwa ada pedoman standar penulisan karya ilmiah untuk memenuhi angka kredit dari unsur pengembangan profesi. Sehubungan itu adalah wajar jika karya guru selalu dinilai belum memenuhi kriteria kegiatan pengembangan profesi yang disusun Biro Kepegawaian Depdiknas.

Menyadari hal itu, melalui diskusi yang intens antara Tim Pengusul dengan Pengurus PGRI Kabupaten Tasikmalaya dan para peserta sosialisasi, diperoleh suatu konklusi bahwa mereka sepakat dan mengharapkan pendampingan langsung dari pihak yang mengetahui kriteria standar penilaian karya ilmiah guru, khususnya dari Tim Jurusan Psikologi Pendidikan dan Bimbingan, sehingga para guru SD di Kabupaten Tasikmalaya mampu membuat karya ilmiah secara mandiri sesuai standar yang ditetapkan.

Permasalahan spesifik yang berhasil diidentifikasi bersama oleh Tim Pengusul dengan Pengurus PGRI Kabupaten Tasikmalaya dan para guru SD peserta sosialisasi adalah sebagai berikut.

1) Para guru SD belum mampu melakukan ragam kegiatan mengembangkan profesi, khususnya dalam penulisan karya tulis ilmiah (KTI) hasil penelitian tindakan kelas (PTK).

2) Para guru SD perlu memperoleh pembinaan dari pihak yang kompeten dalam melakukan PTK di kelas yang dibinanya.

3) Para guru SD perlu memperoleh pebinaan dari pihak yang kompeten dalam menyusun laporan penelitian hasil kegiatan PTK sehingga menghasilkan laporan yang secara subtansi dan fisik layak mendapat angka kredit.

4) Para guru SD perlu memperoleh pembinaan dari pihak yang kompeten dalam menyusun artikel jurnal ilmiah hasil kegiatan PTK.

5) Belum tersedia guru yang kompeten menjadi tutor sebaya pada tingkat ranting PGRI (Kecamatan) yang terampil dan siap melaksanakan sosialisasi ragam jenis pengembangan profesi guru serta menjadi teman sebaya dalam pelaksanaan PTK.

6) Belum tersedia media publikasi umum untuk menyebarluaskan hasil kegiatan pengembangan profesi guru. 


\section{METODE PELAKSANAAN}

Metode yang ditawarkan untuk mendukung realisasi program adalah pelatihan, lokakarya, dan pendampingan. Sasaran kegiatan ini adalah 40 orang yang terdiri atas 39 orang guru SD yang memiliki golongan IVa minimal empat tahun dan satu orang jajaran PGRI yang membidangi pengembangan profesi guru SD. Para guru itu dipilih masing-masing satu orang untuk setiap ranting PGRI yang berdasarkan penilaian pihak PGRI Kabupaten paling kompeten untuk menjadi Tutor Sebaya di masing-masing ranting PGRI.

Kegiatan Pelatihan dan Lokakarya PTK ini ditujukan untuk membantu guru agar mampu melakukan PTK sebagai bagian dari pekerjaan profesionalnya sehari-hari serta mampu menuangkan hasil penelitiannya dalam bentuk laporan penelitian dan artikel pada jurnal ilmiah. Secara rinci, Pelatihan dan Lokakarya bertujuan untuk membantu guru: (1) Memahami Penelitian Tindakan Kelas (PTK) sebagai bagian dari tugas profesional guru; (2) Memahami prinsip-prinsip dan prosedur Penelitian Tindakan Kelas (PTK); (3) Mampu merancang dan menulis proposal PTK; (4) Mampu melakukan PTK (planning, action, observation, and reflection); dan (5) Mampu menyajikan hasil PTK dalam bentuk laporan penelitian dan artikel jurnal ilmiah. Sehubungan itu, luaran yang diharapkan dalam pelatihan dan lokakarya PTK adalah:

1) Tersedia guru yang terampil dan siap melaksanakan sosialisasi ragam jenis pengembangan profesi guru.

2) Terbantunya guru untuk mampu mengembangkan profesi, khususnya dalam penulisan karya tulis ilmiah (KTI) hasil penelitian tindakan kelas (PTK).

3) Terbinanya guru dalam melakukan PTK di kelas yang dibinanya.

4) Terbinanya guru dalam menyusun laporan penelitian dan artikel jurnal ilmiah hasil kegiatan PTK.

5) Tersusunnya laporan penelitian dari kegiatan PTK yang ditulis oleh guru.

6) Terbitnya jurnal edisi khusus yang memuat artikel hasil kegiatan PTK yang ditulis oleh guru.

Spesifikasi materi sosialisasi, model kegiatan dan laporan PTK, artikel jurnal ilmiah, dan jurnal ilmiah yang diterbitkan, wujud fisiknya mengacu kepada ketentuan yang dikeluarkan oleh Pemerintah.

Kegiatan pelatihan dan lokakarya ini dirancang selama 26 jam yang dilakukan selama tiga hari. Sementara itu, proses pendampingan dilakukan selama empat bulan setelah kegiatan pelatihan dan lokakarya selesai dilakukan. Pelaksanaan kegiatan diawali dari perencanaan, pelaksanaan dan diakhiri dengan laporan.

\section{HASIL DAN PEMBAHASAN}

Kegiatan Pelatihan dan Lokakarya PTK ini ditujukan untuk membantu guru agar mampu melakukan PTK sebagai bagian dari pekerjaan 
profesionalnya sehari-hari serta mampu menuangkan hasil penelitiannya dalam bentuk laporan penelitian dan artikel pada jurnal ilmiah. Secara rinci, Pelatihan dan Lokakarya bertujuan untuk membantu guru: (1) Memahami Penelitian Tindakan Kelas (PTK) sebagai bagian dari tugas profesional guru; (2) Memahami prinsip-prinsip dan prosedur Penelitian Tindakan Kelas (PTK); (3) Mampu merancang dan menulis proposal PTK; (4) Mampu melakukan PTK (planning, action, observation, and reflection); dan (5) Mampu menyajikan hasil PTK dalam bentuk laporan penelitian dan artikel jurnal ilmiah. Sebagai respon atas tujuan kegiatan tersebut, muncul beberapa permasalahan yang terekam, antara lain:

1) Pada awal kegiatan, para peserta merasa rendah diri dan merasa tidak akan mampu mengikuti kegiatan secara utuh dan menghasilkan satu karya tulis ilmiah hasil PTK, sehingga ada satu orang calon peserta yang mengundurkan diri.

2) Wawasan mereka tentang metodologi penelitian masih kurang

3) Kemampuan mereka dalam melakukan PTK masih rendah

4) Penguasaan mereka atas landaan konseptual dan teori-teori yang digunakan dalam penelitian sangat minim.

5) Kemampuan mereka dalam menggunakan ICT masih rendah sehingga akses mereka terhadap informasi yang bersumber dari internet sangat minim.

6) Kemampuan menulis yang menggunakan kaidah ilmiah masih rendah.

7) Daya juang mereka untuk mencapai hasil terbaik, perlu ditingkatkan.

8) Daya serap terhadap materi pelatihan dan daya tangkap terhadap arahan pendamping belum memuaskan.

9) Penyelesiaan tugas-tugas relatif lamban dan cukup bervariasi waktu penyelesaiannya.

10) Ada beberapa peserta yang belum terampil menulis dengan menggunakan komputer.

Berdasarkan permasalahan-permasalahan di atas, maka disusun rangkaian kegiatan pelatihan dan lokakarya PTK untuk membina guru agar mampu melakukan merencanakan, melakukan, dan menyusun laporan penelitian yang berlangsung dalam lima tahap berikut.

Pertama, tahap pengembangan materi sosialisasi dan pelatihan. Materi sosialisasi dimaksudkan untuk memberi bekal kepada peserta agar nantinya bisa memberikan sosialisasi ragam kegiatan pengembangan profesi di setiap Ranting PGRI masing-masing, Materi ini merujuk pada pedoman yang dikeluarkan oleh Depdiknas dan dikemas dalam format Power Point dan direkam dalam media CD. Sementara itu, materi pelatihan dikemas dalam bentuk buku pedoman yang nantinya diharapkan menjadi acuan para guru dalam melakukan kegiatan pengembangan profesi khususnya dalam bentuk 
karya tulis ilmiah. Isi materi ini merujuk kepada Kepmendikbud No. 025/0/1995 dan ketentuan lain yang berlaku.

Kedua, tahap pelatihan. Pelatihan merupakan kegiatan awal untuk pembinaan guru. Materi pelatihan yang akan diberikan: 1) Penelitian Tindakan Kelas sebagai Pengembangan Profesi Guru; 2) Penggalian permasalahan dan Kajian Pustaka; 3) Penulisan proposal/rancangan PTK; 4) Penyusunan Laporan Penelitian; 5) Penulisan artikel jurnal. Alokasi waktu pelatihan untuk kelima materi tersebut adalah 26 jam yang dipilah ke dalam tiga hari. Dokumentasi kegiatan pelatihan tampak pada Gambar 1.

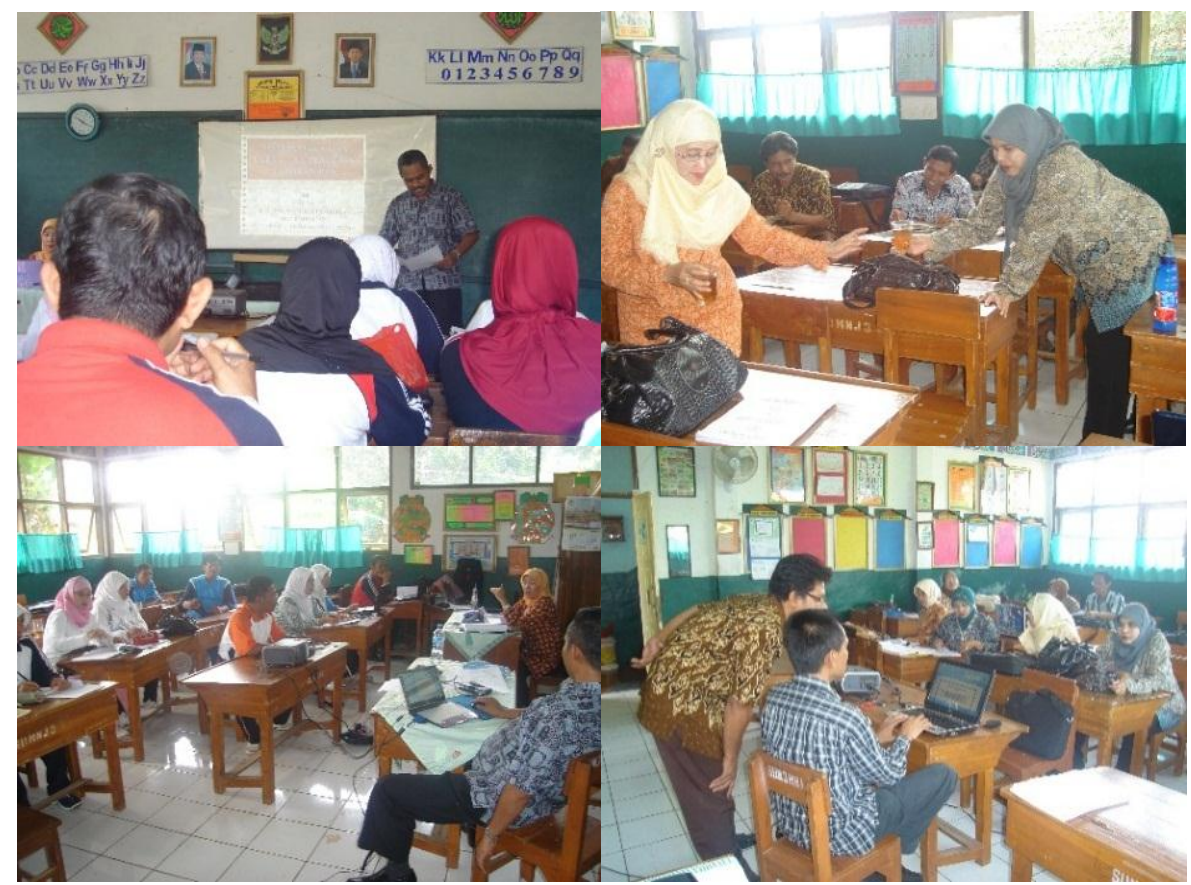

Gambar 1. Kegiatan Pelatihan

Ketiga, tahap pendampingan. Pendampingan ditujukan untuk mendampingi guru dalam melakukan Penelitian Tindakan Kelas (PTK). Pendampingan dilaksanakan oleh dosen dan widyaiswara kepada guru. Bentuk pendampingan meliputi: (1) pelaksanaan PTK dalam bentuk memberi masukan terhadap rencana atau skenario pembelajaran terutama dalam tahapan refleksi; (2) penulisan laporan penelitian dengan memberi arahan cara-cara penulisan laporan penelitian, dan (3) penulisan artikel, bentuk pendampingannya berupa arahan tentang tata cara penulisan artikel.

Pendampingan ditujukan untuk mendampingi guru dalam melakukan Penelitian Tindakan Kelas (PTK). Pendampingan dilaksanakan oleh dosen kepada guru. Bentuk pendampingan yang telah dilaksanakan adalah pelaksanaan PTK dalam bentuk memberi masukan terhadap rencana atau skenario pembelajaran terutama dalam tahapan refleksi dan penulisan laporan penelitian dengan memberi arahan cara-cara penulisan laporan penelitian. Pendampingan dilaksanakan setiap hari minggu dengan melibatkan 4 orang 
dosen masing-masing mendampingi 5 orang guru, seperti tampak pada Gambar 2. Pendampingan telah dilaksanakan sebanyak 4 kali.

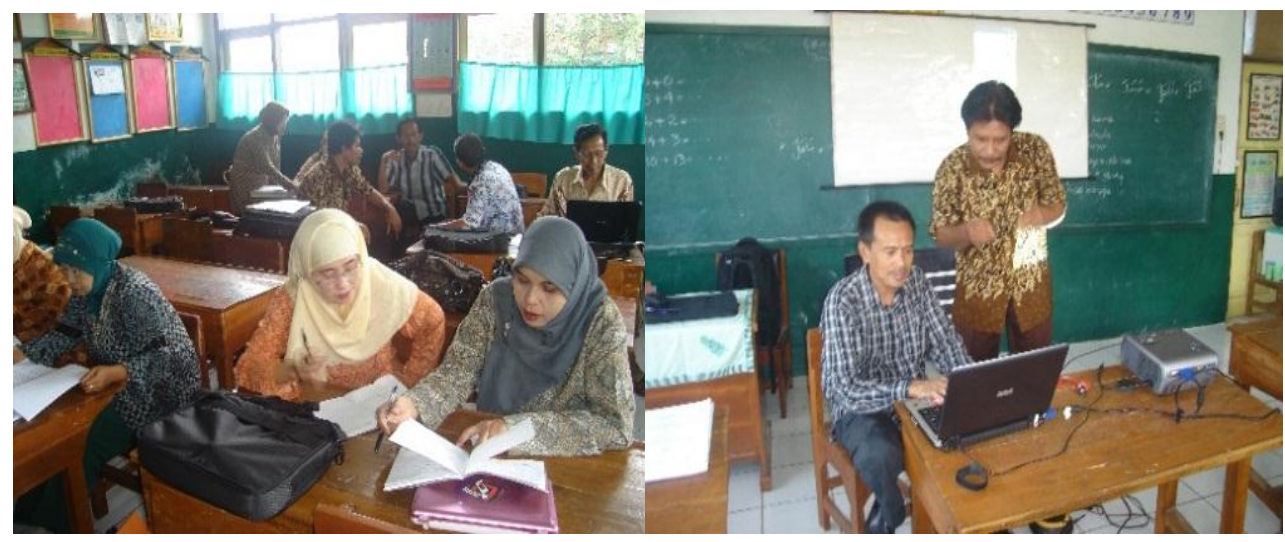

Gambar 2. Kegiatan Pendampingan

Keempat, tahap seminar. Seminar dilakukan untuk menampilkan hasil penelitian. Peserta membuat prasaran atau makalah berdasarkan hasil penelitian. Masukan pada saat seminar dijadikan masukan dalam menganalisis hasil temuan penelitian sebagai bahan perbaikan artikel jurnal.

Kelima, tahap penerbitan jurnal. Penerbitan jurnal adalah kegiatan lanjutan setelah artikel peserta selesai disusun peserta dan diperbaiki dalam kegiatan seminar. Jurnal yang dimaksud adalah berupa edisi khusus yang diterbitkan oleh PGRI Kabupaten Tasikmalaya. Jumlah edisi sekitar 5-8 edisi khusus.

Berdasarkan tahap atau langkah yang dilakukan di atas, kegiatan program ini diperoleh hasil sebagai berikut:

1) Sebanyak 27 orang guru SD Golongan IVa mengikuti kegiatan pelatihan secara utuh selama 26 jam pelajaran.

2) Terlaksana empat kali pendampingan dalam kegiatan perencanaan, pelaksanaan, dan penulisan laporan PTK.

3) Tersedia 27 laporan hasil PTK yang sendiri oleh setiap peserta dengan bimbingan dan arahan tim pendamping.

4) Tersedia 27 artikel hasil PTK yang memungkinkan dimuat dalam terbitan berkala lokal maupun nasional.

5) Terbentuk lembaga penerbitan "MANONJAYA" untuk publikasi hasil-hasil PTK guru.

6) Dua artikel terbaik siap dimuat pada berkala yang diterbitkan oleh lembaga di lingkungan UPI. 


\section{KESIMPULAN}

Kegiatan ini sangat dirasakan manfaatnya oleh peserta Guru SD Golongan IVa yang mau naik ke IVb, karena merupakan solusi atas masalah sulitnya naik pangkat dari IVa ke IVb dan seterusnya. Kesulitan mereka mengumpulkan 12 kredit dari kegiatan pengembangan profesi, yang antara lain adalah karya tulis dalam bentuk PTK, melalui kegiatan ini dapat diperoleh solusinya. Atas dasar itu, para peserta dan pengurus PGRI berkeinginan untuk merancang dan melanjutkan program ini melalui kegiatan swadaya dan swadana. Partisipasi tim pelaksana program ini dalam kegiatan mereka nanti sangat diharapkan terutama sebagai nara sumber dan pendamping. Pihak PGRI berkeinginan melibatkan banyak peserta dalam kegiatan tersebut sehingga nantinya semua guru memiliki kemampuan menulis karya ilmiah yang sesuai dengan standar yang diharapkan tim penilai angka kredit pengembangan profesi guru.

Berdasarkan hasil yang telah diperoleh, dari perspektif PGRI, kegiatan ini merupakan pelaksanaan program strategis untuk memberikan layanan pengembangan kompetensi guru, khususnya dalam merencanakan, melaksanakan, dan membuat laporan hasil PTK. Adapun dari perspektif penentu kebijakan, kegiatan ini merupakan kepanjangan tangan untuk mensosialisasikan ragam kegiatan pengembangan profesi kepada para guru di lapangan, khususnya berupa karya tulis ilmiah hasil PTK.

\section{REFERENSI}

Peraturan Bersama Menteri Pendidikan Nasional dan Kepala Badan Kepegawaian Negara Nomor 03/V/Pb/2010 dan Nomor 14 Tahun 2010 tentang Petunjuk Pelaksanaan Jabatan Fungsional Guru Dan Angka Kreditnya.

Peraturan Manteri Pendidikan Nasional Nomor 35 Tahun 2010 tentang Petunjuk Teknis Pelaksanaan Jabatan Fungsional Guru dan Angka Kreditnya.

Peraturan Menteri Negara Pendayagunaan Aparatur Negara dan Reformasi Birokrasi Nomor 16 Tahun 2009 tentang Jabatan Fungsional Guru dan Angka Kreditnya.

Peraturan Menteri Pendidikan Nasional Nomor 38 Tahun 2010 tentang Penyesuaian Jabatan Fungsional Guru.

Pusat Pengembangan Profesi Pendidik. (2010). Pembinaan dan pengembangan profesi guru buku 1: Pedoman pengelolaan pengembangan keprofesian berkelanjutan. Jakarta: Pusat Pengembangan Profesi Pendidik, BPSDM dan PMP Kementerian Pendidikan Dan Kebudayaan. 
Pusat Pengembangan Profesi Pendidik. (2010). Pembinaan dan pengembangan profesi guru Buku 2: Pedoman pelaksanaan penilaian kinerja guru (PK Guru). Jakarta: Pusat Pengembangan Profesi Pendidik, BPSDM dan PMP Kementerian Pendidikan Dan Kebudayaan.

Pusat Pengembangan Profesi Pendidik. (2010). Pembinaan dan pengembangan profesi guru Buku 4: Pedoman kegiatan pengembangan keprofesian berkelanjutan (PKB) dan angka kreditnya. Jakarta: Pusat Pengembangan Profesi Pendidik, BPSDM dan PMP Kementerian Pendidikan Dan Kebudayaan.

Pusat Pengembangan Profesi Pendidik. (2010). Pembinaan dan pengembangan profesi guru Buku 5: Pedoman penilaian kegiatan pengembangan keprofesian berkelanjutan (PKB), Pedoman untuk mendukung pelaksanaan tugas Tim Teknis penilai Publikasi Ilmiah Guru dan Karya Inovatif Guru. Jakarta: Pusat Pengembangan Profesi Pendidik, BPSDM dan PMP Kementerian Pendidikan Dan Kebudayaan.

Pusat Pengembangan Profesi Pendidik. (2012). Pembinaan dan pengembangan profesi guru buku 1: Pedoman pengelolaan pengembangan keprofesian berkelanjutan. Edisi Revisi. Jakarta: Pusat Pengembangan Profesi Pendidik, BPSDM dan PMP Kementerian Pendidikan Dan Kebudayaan.

Pusat Pengembangan Profesi Pendidik. (2012). Pembinaan dan pengembangan profesi guru Buku 2: Pedoman pelaksanaan penilaian kinerja guru (PK Guru). Edisi Revisi. Jakarta: Pusat Pengembangan Profesi Pendidik, BPSDM dan PMP Kementerian Pendidikan Dan Kebudayaan.

Pusat Pengembangan Tenaga Kependidikan Badan Pengembangan SDM Pendidikan dan Penjaminan Mutu Pendidikan, Kementerian Pendidikan Nasional. (2011). Materi Kegiatan ToT Calon Master Trainers dan Trainer Calon Penilai Kinerja Guru.

Supardi. (2007). Guru Golongan IV/a Bisa Naik Pangkat ke Golongan IV/b Menggunakan "CAR". Artikel Pendidikan. kemdikbud.go.id.

Universitas Pendidikan Indonesia. (2014). Panduan penulisan karya ilmiah 2014. Bandung: Universitas Pendidikan Indonesia. 